Annals of Warsaw University of Life Sciences - SGGW

Land Reclamation No 49 (3), 2017: 213-221

(Ann. Warsaw Univ. of Life Sci. - SGGW, Land Reclam. 49 (3), 2017)

\title{
The overconsolidation ratio of eemian gyttja determination
}

\author{
MAREK BAJDA, EDYTA E. MALINOWSKA \\ Faculty of Civil and Environmental Engineering, Warsaw University of Life Sciences - SGGW
}

\begin{abstract}
The overconsolidation ratio of eemian gyttja determination. The overconsolidation ratio is an important parameter that determines the value of stress history exerted in the past on the subsoil in the geotechnical engineering. Overconsolidation ratio $(O C R)$ is one of the main criteria conditioning soil behavior and characteristics. To know the relation between geological background, history and mechanical behavior of the soil, aims a knowledge that can help engineers who often have to predict soil behavior based upon the soil geological history and a geotechnical data. In order to evaluate the overconsolidation ratio of eemian gyttja, it is necessary to restore this soft soil as much as possible to the in situ conditions. The eemian gyttja is an organic soft soil from the "Zoliborz channel" located in Warsaw. These soils are used as a base construction in the foundation engineering. In practical geotechnical engineering, evaluation of stress history is based on the overconsolidation ratio. The overconsolidation ratio is one of the basic parameters for the geotechnical design of the structure. Determination of this parameter using for example dilatometer tests, is usually based on empirical formulas which were established in different countries. Therefore, regional geotechnical conditions could have substantially affected on the empirical relationships. The laboratory tests are used to determinate the preconsolidation pressure and then the overconsolidation ratio. The laboratory tests were made in the automatic oedometer and the in situ tests were carried out on the dilatometer test $(D M T)$. The paper presents results of determination the overconsolidation ratio of eemian gyttja from the laboratory and in situ tests. The studies have shown that the values of the overconsolidation ratio determination from the laboratory tests are a little higher than determination from the in situ tests.
\end{abstract}

Key words: overconsolidation ratio $(O C R)$, preconsolidation pressure, eemian gyttja, automatic oedometer, in situ tests

\section{INTRODUCTION}

Preconsolidation pressure is an important soil parameter that represents the stress history of a subsoil. In situ soil has been subjected to a maximum overload in its history. Overconsolidation ratio $(O C R)$ is described as the ratio of previous maximal preconsolidation pressure $\left(\sigma_{p}^{\prime}\right)$ and current effective geostatic stress $\left(\sigma^{\prime}{ }_{v o}\right)$. The soil can be nonconsolidated $(O C R<1.0)$, normally consolidated (1.0-1.5), overconsolidated (1.5-10.0) and higly overconsolidated $(O C R>10.0)$. The reduction of in situ pressure can be caused by natural geological processes (i.e. melting of glacial ice, tectonic movements, precipitation of cementing agents) or human effects (i.e. excavation). When the present effective vertical stress is less than this maximum, the soil is overconsolidated.

The overconsolidation ratio is one of the basic parameters for the geotechnical design of the structure. In situ dilatometer test is usually used to determinate the overconsolidation ratio, based on empirical regional formulas (Bajda and Skutnik 2010, Lechowicz et al. 2014). In the laboratory tests, the preconsolidation 
pressure is determined out of the results of the oedometer test and then the $O C R$ is calculated. The most important is to determinate the preconsolidation pressure from the laboratory tests. It is necessary to indicate the proper average value of time for the transition from primary to the secondary compression $-t_{a}$ (Malinowska 2016).

There is a number of theoretic and empiric correlations to establish the $O C R$ (Mayne 2001). However, it is essential to try the theory in practice for each type of the soil under the geological conditions (Szymański 2000). Nevertheless, it is usually confined with the opinion that due to the size of glacier the majority of soils prevailing in our territory are overconsolidated or highly overconsolidated, and that the $O C R$ values decrease with the declination of the depth (Urbaitis et al. 2016).

\section{MATERIAL AND METHODS}

In situ investigations using dilatometer test (DMT) were performed in the "Zoliborz channel" that is located in the western part of Warsaw, where sedimentation of organic soils took place during the Eemian Interglacial. The channel is about $12 \mathrm{~km}$ long and nearly $800 \mathrm{~m}$ wide in its central part. In the "Zoliborz channel", the organic soils, i.e. organic mud and gyttja, reach a thickness of up to $10 \mathrm{~m}$ (Fig. 1). The DMT test was made from the bottom of excavation with a depth of $5.0 \mathrm{~m}$. The calculation included the weight of excavated soil.

The type of soil samples, the laboratory methods and in situ methodology were described by Bajda and Malinowska (2016).


FIGURE 1. Location and typical cross-section of the test site (Bajda and Malinowska 2016) 
The physical laboratory tests were carried out on two undisturbed eemian gyttja's samples and included: general index tests for classification and characterization of the gyttja according to PN-EN ISO 14688:2006 - density, grain size distribution and measurement of compressibility tests. The samples of the eemian gyttja have been retrieved from $7.2 \mathrm{~m}$ depth $(2.2 \mathrm{~m}$ below the bottom of excavation) using a Shelby sampler. The physical properties of tested samples are shown in Table 1.

To obtain the overconsolidation ratio from in situ test, the DMT test was carried out in the analyzed subsoil.

The methodology of standard DMT test is widely known and detailed procedure for conducting the test which has been presented by Marchetti (Marchetti 1980, Marchetti et al. 2001, Marchetti et al. 2008).

Profiles of data from the DMT test were carried out in the subsoil of the test site, as profiles of the material index $\left(I_{D}\right)$,

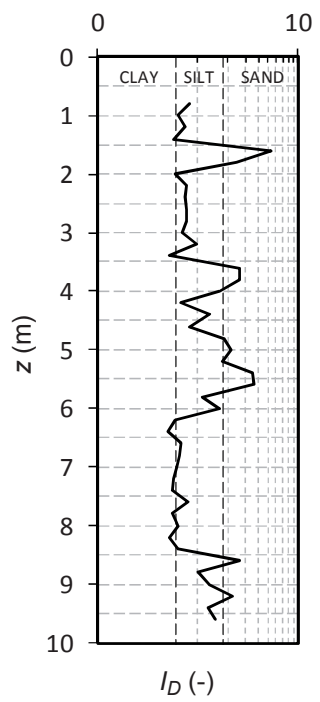

TABLE 1. Index properties of eemian gyttja at the test site (Bajda and Malinowska 2016)

\begin{tabular}{|l|c|}
\hline Physical properties & $\begin{array}{c}\text { "Skiernie- } \\
\text { wicka- } \\
\text {-Wolska" }\end{array}$ \\
\hline Water content $(\%)$ & 96.0 \\
\hline Density of solid particles $\left(\mathrm{kN} \cdot \mathrm{m}^{-3}\right)$ & 2.25 \\
\hline Bulk density $\left(\mathrm{kN} \cdot \mathrm{m}^{-3}\right)$ & 1.38 \\
\hline Dry density $\left(\mathrm{kN} \cdot \mathrm{m}^{-3}\right)$ & 0.70 \\
\hline Organic matter content $(\%)$ & 20.0 \\
\hline Initial void ratio $(-)$ & 2.28 \\
\hline Porosity $(-)$ & 0.7 \\
\hline
\end{tabular}

constrained modulus $(M)$, undrained shear strength $\left(c_{u}\right)$ and lateral stress index $\left(K_{D}\right)$ are presented in Figure 2.

Different methods, known in the geotechnical research, were used to calculate the overconsolidation ratio (OCR) of eemian gyttja. The overconsolidation ratio is defined as:

$O C R=\frac{\sigma_{p}^{\prime}}{\sigma_{v}^{\prime}}$

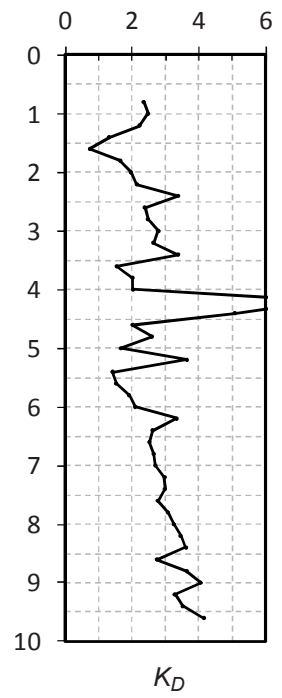

FIGURE 2. Profile of data from DMT test 
where:

$\sigma_{p}^{\prime}$ - preconsolidation pressure;

$\sigma_{v}^{\prime}-$ vertical effective stress.

The value of the preconsolidation pressure $\left(\sigma_{p}^{\prime}\right)$ is usually determined from and on the results of oedometer tests. The preconsolidation pressure can be also determined from DMT data according to formula (Mayne 1995):

$\sigma_{p}^{\prime}=0.51\left(p_{0}-u_{0}\right)$

where:

$p_{0}$ - corrected DMT contact pressure; $u_{0}$-hydrostatic water pressure.

In situ tests, e.g. dilatometer tests, can characterize the variation of $O C R$ with depth and are valuable tools for geotechnical engineers.

Using the correlation between the $O C R$ and the lateral stress index $\left(K_{D}\right)$ for soils with the material index $I_{D}>2.0$ and for cohesive soils where $I_{D}<1.2$, the following correlations were proposed by Marchetti (1980):

$O C R=\left(0.67 \cdot K_{D}\right)^{1.91}$

$O C R=\left(0.5 \cdot K_{D}\right)^{1.56}$

It is important to note that the estimation of the overconsolidation ratio from dilatometer tests depends on empirical and local experience. Many studies have been performed to improve the original correlations proposed by Marchetti, however they were mostly limited to mineral soils.

Experience from organic soils indicates that the relation between the overconsolidation ratio $(O C R)$ and the lateral stress index $\left(K_{D}\right)$ is as follows (Lechowicz 1997):
$O C R=\left(0.45 \cdot K_{D}\right)^{1.40}$

To determinate the overconsolidation ratio from laboratory test, the automatic oedometer test (ACONS) was carried out in the analyzed subsoil.

To receive the overconsolidation ratio from the laboratory tests, the preconsolidation pressure from the oedometer tests should be performed first. The samples were divided into three groups according to the known preconsolidation pressure, load duration and load ratio. The samples were consolidated up to pressure of $120 \mathrm{kPa}$, then the pressure was released to $25 \mathrm{kPa}$, and then the standard consolidation tests were started from $120 \mathrm{kPa}$ to $1,500 \mathrm{kPa}$. To determinate the preconsolidation pressure, mainly the relationship between the stress and void ratio or strain is used. Nevertheless, it is extremely hard to find the average value of time for the transition from primary to the secondary compression, called $t_{a}$, because of the average value of time for the transition and from secondary to the tertiary compression is called $t_{k}$, that is starting right after the primary consolidation (Malinowska 2016).

There were several methods used to estimate preconsolidation pressure presented in Figure 3. Tavenas et al. (1979), Sridharan et al. (1991) and Senol new methods (Senol and Saglamer 2000) are the direct determination methods of preconsolidation pressure, whereas Casagrande (1936), Van Zelst (1948), Schmertmann (1953) and Sällfors methods (1975) are the graphical ones. In this paper, seven of them that utilizes different axes are considered:

Casagrande method: $e-\log \left(\sigma v^{\prime}\right)$

Van Zelst method: $\Delta H / H-\log \left(\sigma v^{\prime}\right)$

Schmertmann method: $e-\log \left(\sigma v^{\prime}\right)$ 
Sällfors method: $E-\sigma \mathrm{v}$ ' Tavenas et al. method: $\sigma v^{\prime} \cdot(\Delta H / H)-\sigma v^{\prime}$

Sridharan et al. method:

a)
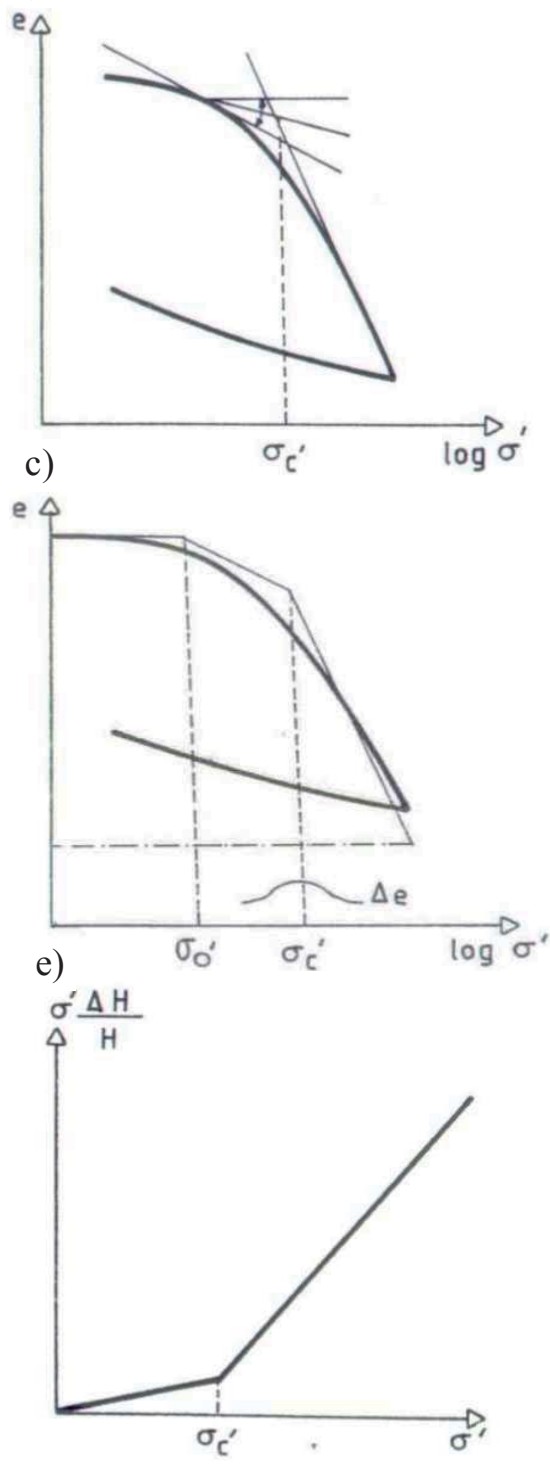

(9) $\log (1+e)-\log \left(\sigma v^{\prime}\right)$

Senol and Saglamer method:

(10) $\sigma v^{\prime} \cdot(\Delta H / H)-\log \left(\sigma v^{\prime}\right)$

b)

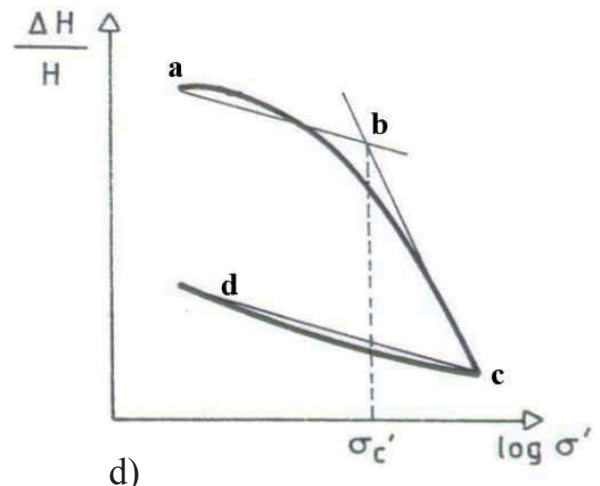

E

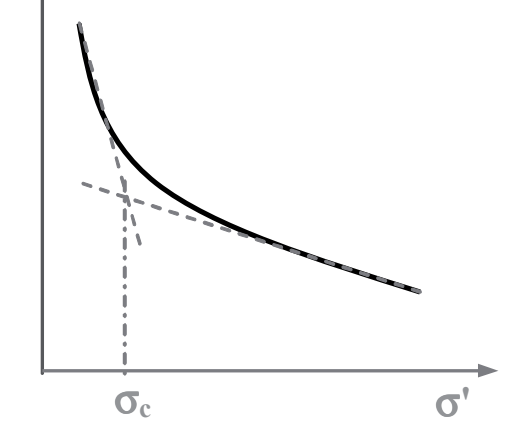

f)

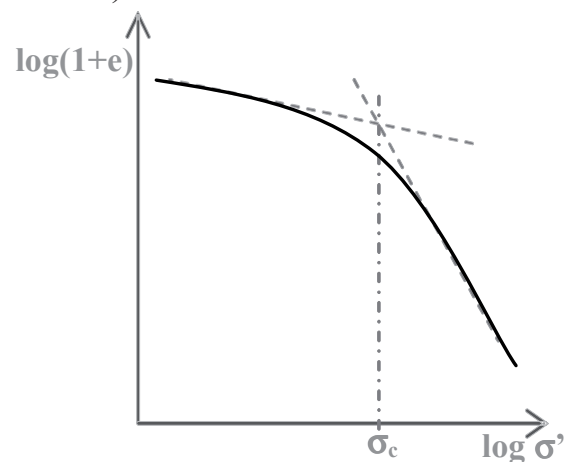

FIGURE 3. Methods for determination the preconsolidation pressure: a - the Casagrande method, $\mathrm{b}$ - the Van Zelst method, c - the Schmertmann method, d - the Sällfors method, e - the Tavenas et al. method, $\mathrm{f}-$ the Sridharan et al. method 


\section{RESULTS}

Using Equations (4) and (5), the SDMT profiles, shown as values of the overconsolidation ratio and the preconsolidation pressure, were determined in the subsoil of the test site (Fig. 4).

To receive the overconsolidation ratio from the laboratory tests, the preconsoli- dation pressure from the oedometer tests (ACONS) were performed first. There are only some, the most correlated to the in situ test results presented in Figures 5 and 6.

The results with seven methods used for obtaining the overconsolidation ratio $(O C R)$ are presented in Table 2.

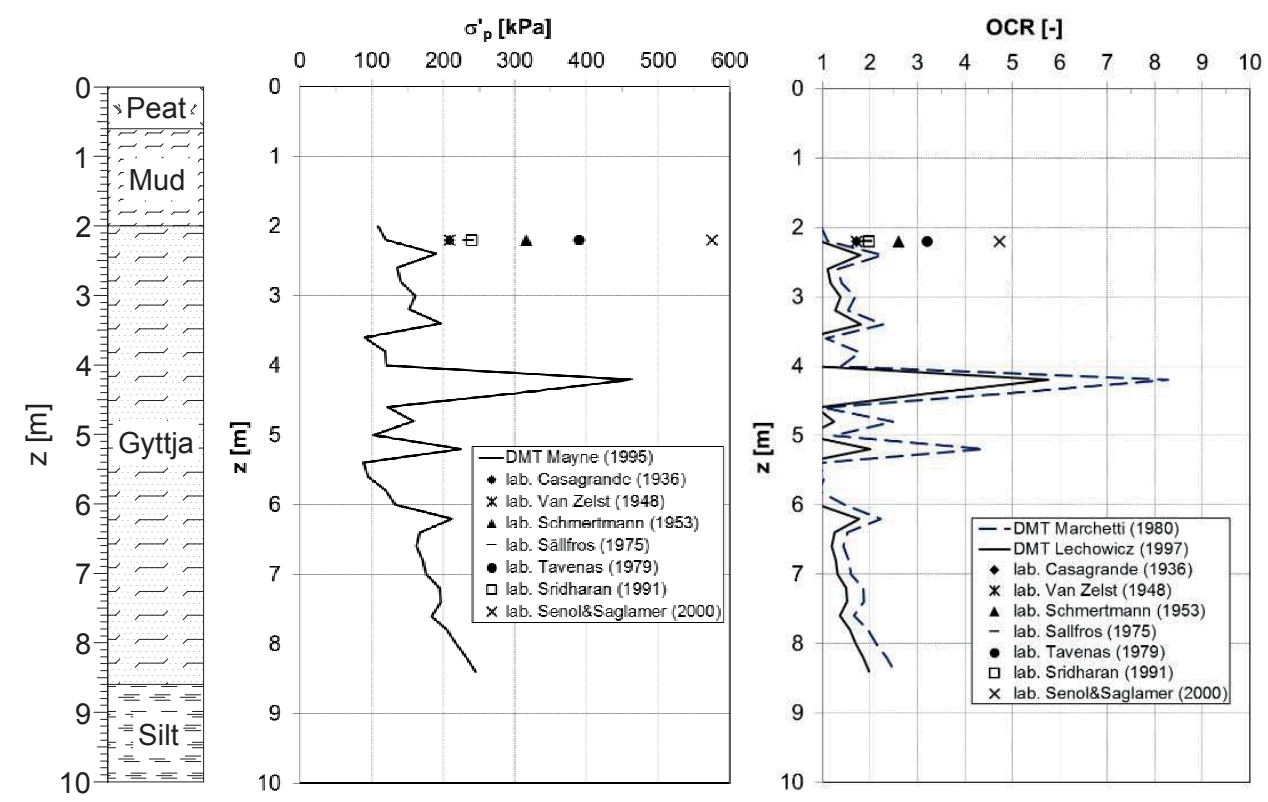

FIGURE 4. Profiles of the preconsolidation pressure $\sigma_{p}^{\prime}$ and the overconsolidation ratio $(O C R)$ from the DMT test and values obtained from the oedometer test for the subsoil of the test site
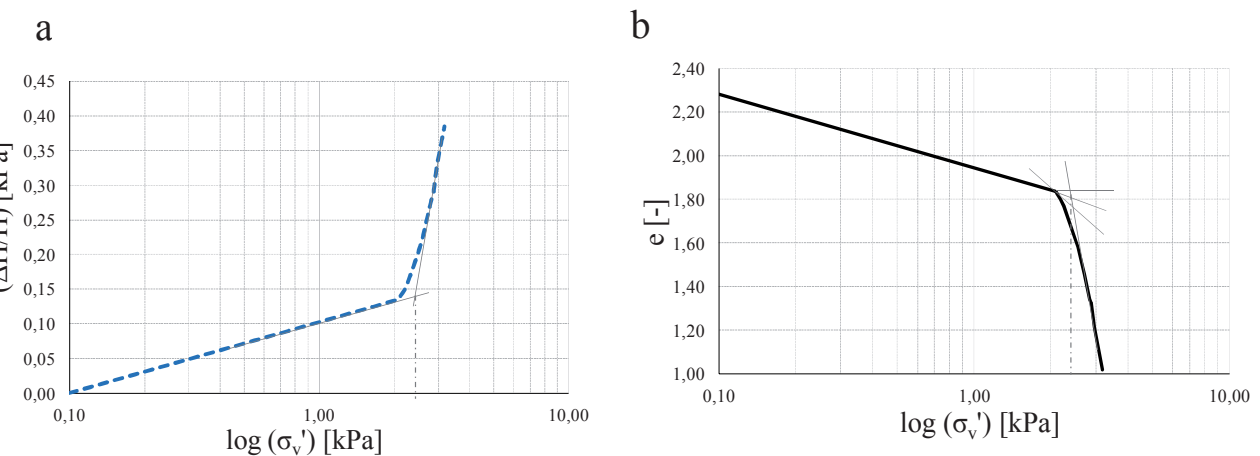

FIGURE 5. Methods for determination the preconsolidation pressure: a - the Casagrande method (1936), b - the Van Zelst method (1948) 
a

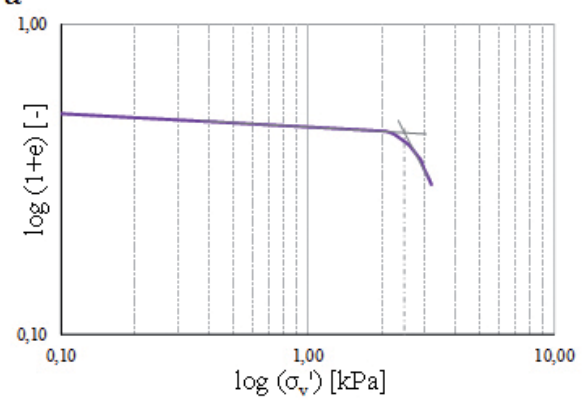

$\mathrm{b}$

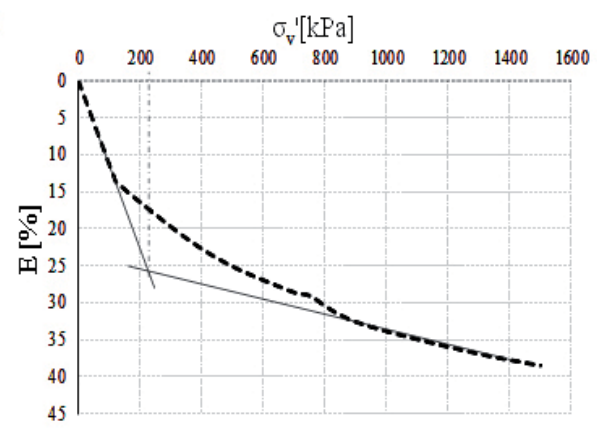

FIGURE 6. Methods for determination the preconsolidation pressure: $\mathrm{a}-$ the Sridharan et al. method (1991), b - the Sällfors method (1975)

TABLE 2. The methods used for obtaining the overconsolidation ratio $(O C R)$

\begin{tabular}{|l|c|}
\hline Methods & $O C R$ \\
\hline Casagrande method & 1.73 \\
\hline Van Zelst method & 1.89 \\
\hline Schmertmann method & 2.61 \\
\hline Sällfors method & 1.90 \\
\hline Tavenas et al. method & 3.14 \\
\hline Sridharan et al. method & 1.98 \\
\hline Senol and Saglamer method & 4.76 \\
\hline
\end{tabular}

\section{SUMMARY AND CONCLUSIONS}

For in situ tests the overconsolidation ratio is obtained directly from the SDMT tests but the correlations presented in the literature are regional and cannot be used uncritically.

At first, in the laboratory conditions, the vertical strain under different stress values should be determined. Then the preconsolidation stress is obtained and the overconsolidation ratio is calculated. A comparison between results obtained from SDMT tests and laboratory tests has been made.

The following conclusions can be drawn from the in situ and laboratory test results presented in the present paper:
- in situ tests, such as SDMT, are the best way of geotechnical parameters estimation for organic soils. It is due to high sensitivity of these soils to changes of water content and difficulties with good quality undisturbed soil sample collection for laboratory tests;

- the value of the overconsolidation ratio received by using empirical formulas on the basis of results of SDMT, differs from values obtained on the basis of oedometer tests;

- for the in situ test results, the overconsolidation ratio has been obtained using some formulas and the values are between 1.0 and 1.3;

- for the laboratory oedometer test results, the overconsolidation ratio has been obtained by seven methods and the values are between 1.7 and 4.76;

- the values of the overconsolidation ratio obtained from the laboratory methods are higher than values from the in situ ones;

- the relationship between void ratio and logarithm of the vertical effective stress seems to be the most accurate for determination of the preconsolidation pressure;

- to obtain the overconsolidation ratio, in both laboratory and in situ meth- 
ods, the local conditions should be considered;

- further studies are necessary to verify the correlations used for organic soils to find the empirical regional formulas for estimation of the overconsolidation ratio.

\section{REFERENCES}

BAJDA M., MALINOWSKA E. 2016: Ocena parametrów odkształceniowych gytii na podstawie badań terenowych i laboratoryjnych. Acta Sci. Pol. Architectura 15 (3), 17-30.

BAJDA M., SKUTNIK Z. 2010: Determination of mechanical parameters of organic soil using CPT and SCPT. Proc. XIV Danube-European Conf. Geotech. Eng. Bratislava, Slovak University of Technology, 1-8.

CASAGRANDE A. 1936: Determination of the Preconsolidation Load and its Practical Significance. Proc. 1st Int. Conf. Soil Mech. Found. Eng. Cambridge, Mass. 3, 60-64.

LECHOWICZ Z. 1997: Undrained shear strength of organic soils from dilatometer test. Ann. of Warsaw Agricult. Univ. - SGGW, Land Reclam. 28, 97-105.

LECHOWICZ Z., BAJDA M., RABARIJOELY S., WRZESINSKI G. 2014: Use Of SDMT for the evaluation of the geotechnical parameters of organic soils. In: CPTU and DMT in soft clays and organic soils, Z. Młynarek, J. Wierzbicki (Eds). Poznań: Wydawnictwo Exemplum Poznań, 107-118.

MALINOWSKA E.E. 2016: Tertiary compression of Polish peat. Sci. Rev. - Eng. Environ. Sci. 25 (4), 507-517.

MARCHETTI S. 1980: In Situ Tests by Flat Dilatometer. J. Geotech. Eng. Div. ASCE. 106, GT3. Proc. Paper 15290, 299-321.

MARCHETTI S., MONACO P., TOTANI G., CALABRESE M. 2001: The flat dilatometer test (DMT) in soil investigations.
$A$ report by the ISSMGE Committee TC16. in Procedings IN SITU.

MARCHETTI S., MONACO P., TOTANI G., MARCHETTI D. 2008: In Situ Tests by Seismic Dilatometer (SDMT). Proc. Res. Pract. Geotech. Eng. ASCE Geotech. Spec. Publ. 180, 292-311.

MAYNE P.W. 1995: Profiling yield stresses in clays by in-situ tests. Trans. Res. Rec. 1479. National Academy Press, Washington, D.C., 43-50.

MAYNE P.W. 2001: Stress-strain-strengthflow parameters from enhanced in-situ tests. Proc. Inter. Conf. on In-Situ Meas. Soil Prop. Case Hist. Bali, Indonesia, 27-48.

PN-EN ISO 14688:2006. Geotechnical investigation and testing. Identification and classification of soil.

SÄLLFORS G. 1975: Preconsolidation pressure of soft, high-plastic clays. $\mathrm{PhD}$ thesis, Geotechnical Department, Chalmers University of Technology, Göteborg [typescript].

SCHMERTMANN J.H. 1953: Undisturbed Consolidation Behaviour of Clay. Trans. ASCE 120, 1201.

SENOL A., SAGLAMER A. 2000: Determination of Preconsolidation Pressure with a New Strain Energy-Log Stress Method. Electr. J. Geotech. Eng. 5, 1-5.

SRIDHARAN A., ABRAHAM B.M., JOSE B.T. 1991: Improved technique for estimation of pre-consolidation pressure. Géotechnique 41 (2), 263-268,

SZYMAŃSKI A. 2000: The assessment of overconsolidation ratio in glacial soils on the basis of cone penetration tests. Ann. Warsaw Agricult. Univ. Land Reclam. 29, 51-62.

TAVENAS F., Des ROSIERS J.P., LEROUEIL S., La ROCHELLE P., ROY M. 1979: The Use of Strain Energy as a Yield and Creep Criterion for Lightly Overconsolidated Clays. Géotechnique 29 (3), 285-303.

URBAITIS D., LEKSTUTYTE I., GRIBULIS D. 2016: Overconsolidation Ratio Determination of Cohesive Soil. Proc. 
13th Baltic Sea Geotech. Conf. Geotech. Probl. in Baltic Sea Reg., 108-113. doi: http://doi.org/10.3846/13bsgc.2016.014.

Van ZELST T.W. 1948: An Investigation of the Factors Affecting Laboratory Consolidation of Clay. Proc. Sec. Int. Conf. Soil Mech. Found. Eng., Rotterdam, Holand, Vol. 7, 52-61.

Streszczenie: Wyznaczanie wskaźnika prekonsolidacji gytji eemskiej. Wskaźnik prekonsolidacji jest ważnym parametrem geotechnicznym określającym historię gruntu. Jest jednym z głównych kryteriów zachowania się gruntu pod obciążeniem. Gytja eemska jest gruntem organicznym z podłoża tzw. rynny żoliborskiej w Warszawie. $\mathrm{W}$ badaniach terenowych wskaźnik prekonsolidacji $(O C R)$ jest określanych $\mathrm{z}$ badań DMT. W celu uzyskania wskaźnika prekonsolidacji badań laboratoryjnych niezbędne jest wyznaczenie zależności odkształcenia w czasie oraz wyznaczenie naprężenia prekonsolidacji. W artykule przedstawione są wyniki badań w kierunku wy- znaczenia wskaźnika prekonsolidacji, zarówno z badań terenowych, jak i laboratoryjnych. Wyniki badań wskazują że wartość wskaźnika prekonsolidacji wyznaczona $\mathrm{z}$ badań laboratoryjnych jest wyższa niż z badań terenowych. Niemniej jednak zależności stosowane $\mathrm{w}$ badaniach terenowych są regionalne i powinny być rozszerzone o dalsze badania, w celu zweryfikowania stosowanych korelacji w gruntach organicznych w poszukiwaniu empirycznych wzorców do oszacowania wskaźnika.

MS received July 2017

\section{Authors' address:}

Marek Bajda, Edyta E. Malinowska

Wydział Budownictwa i Inżynierii Środowiska SGGW

ul. Ciszewskiego 6, 02-776 Warszawa

Poland

e-mail:marek_bajda@sggw.pl edyta_malinowska@sggw.pl 